\title{
Water Hazard Assessment in Active Shafts in Upper Silesian Coal Basin Mines
}

\author{
Przemystaw Bukowski
}

Received: 11 March 2010/Accepted: 11 March 2011/Published online: 13 August 2011

(c) The Author(s) 2011. This article is published with open access at Springerlink.com

\begin{abstract}
Since 1976, there have been six inrushes of water into shaft mine workings in the Upper Silesian Coal Basin in Poland, with two of the more serious events occurring during the last 3 years. A safety assessment was conducted, considering inflow intensity, the amount of suspended material contained in the water flowing into the shaft, the proportion of water-bearing formations in the vertical profile, the condition of the shaft lining and safety pillar, and the history of the shaft. A risk assessment system is proposed to classify mine shafts with respect to the risk of a water hazard occurring, based on these factors. Each of the risk factors was assigned a weight, based on their relative significance, and then a method of evaluating each of these factors was developed. The proposed approach may be the basis for a more detailed, expert system for timely assessment of water hazard risk analysis. It may also be possible to adapt it to different geological and mining conditions.
\end{abstract}

Keywords Hazard analysis - Mine shaft · Poland . Upper Silesian Coal Basin · Water hazard

\section{Introduction}

Water inrushes have repeatedly caused damage to mine shafts in Poland. The inrushes have usually been sudden and unexpected. Most often, they have occurred during mine construction or expansion and shaft sinking, although they may occur at any stage of a mine's development when

P. Bukowski $(\square)$

Central Mining Inst, Plac Gwarków 1, 40-166 Katowice, Poland

e-mail: pbukowski@gig.eu water-bearing formations are intercepted or approached. The water can contain loose material (mainly rock) and the water pressure can be intense, resulting in a dangerous situation for the staff. When dealing with a known possibility of such an event, mine construction can be modified to limit the potential danger, by methods such as: shaft face fencing, dewatering, lining of various types (including the caisson method), grout injection into the rock mass around the mine working, rock mass freezing, and face mining with advance protective drilling (Rogoż 2004; Wilk 2003).

Nowadays, mining in Poland's Upper Silesian Coal Basin (USCB) rarely involves new shaft development; instead, existing underground infrastructure is being extended. Thus, the likelihood of water inrushes has been reduced, though they still sporadically occur; two very serious events have occurred within the last 3 years.

\section{Hydrogeological Conditions in the USCB}

Mine shafts in the USCB strike through various stratigraphic formations of overburden before they reach the bituminous coal deposits (locally known as hard coal, to distinguish it from lignite). Part of the basin, hydrogeological subregion I, is 'hydrogeologically exposed', meaning that the overburden strata (mainly unconsolidated sandy-clayey quaternary formations and Triassic carbonate and terrigenic formations) and coal seams are hydrologically recharged by permeable overlying strata; the rest, hydrogeological subregion II, is 'hydrogeologically isolated', meaning that the overburden (which consists of unconsolidated quaternary formations and both unconsolidated and consolidated paleogenic rock fragments) is overlain by relatively impermeable strata (Bukowski et al. 2006; Fig. 1). 
Fig. 1 Generalized lithology within the Upper Silesian Coal Basin, according to Bukowski et al. (2006)

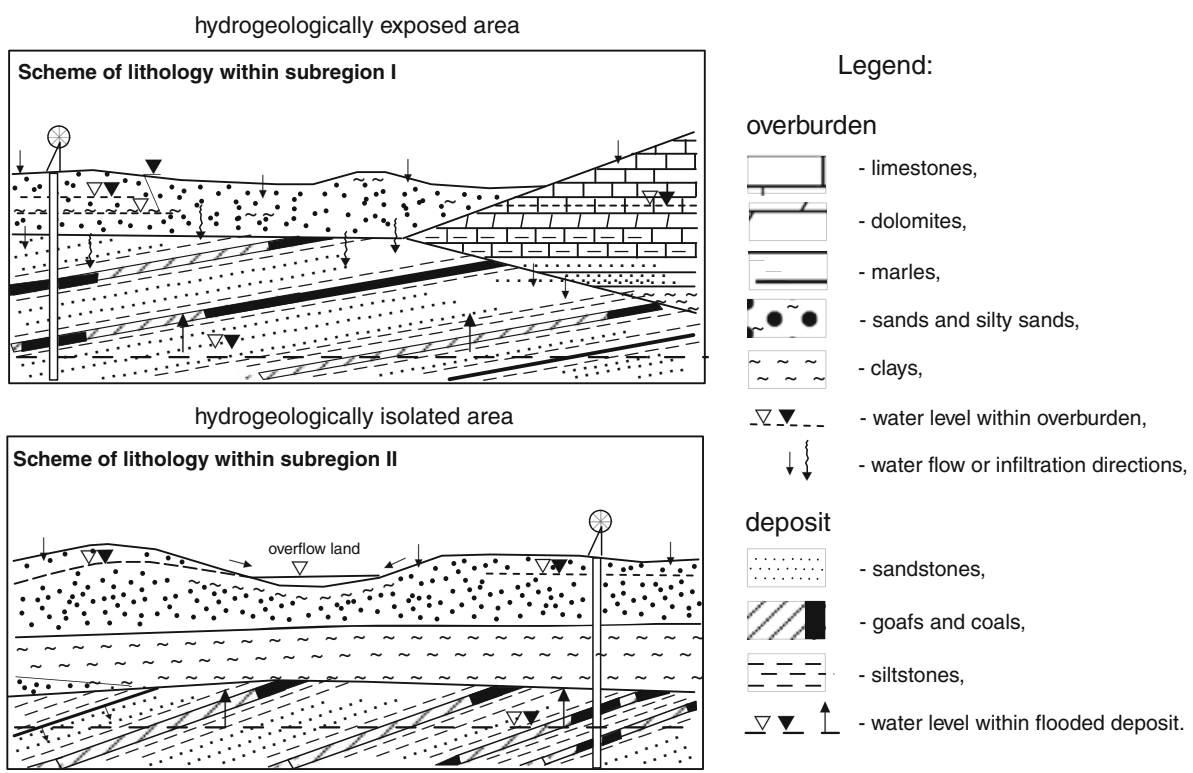

Since the 1970s, the potential water hazards in the mines in Poland have been classified based on the source of the problematic water (Konstantynowicz 1971; Marchacz et al. 1965). The sources are of two types:

Group I: relatively unconstrained water sources, which include:

surface reservoirs and water courses,

water reservoirs in mine workings, and

water-filled karstic voids (Rogoż 2004).

Group II: relatively constrained water sources, which include:

water-bearing strata,

water-bearing faults, fissures, and cavities, and

non-plugged boreholes.

The main hazards for mines in the USCB have been mine workings that penetrated or closely approached water-saturated Quaternary strata. In addition, in the northern part of the USCB, below the Quaternary formations, saturated karstic carbonate formations and Triassic sandstone formations were potentially hazardous. In the southern and southwestern part of the USCB, saturated, weakly consolidated sedimentary formations (the Dębowieckie Beds) were problematic.

Saturated formations between the coal seams (interburden), such as the Krakow Sandstones Series and Upper Silesian Sandstone Series (Fig. 2), have also been a water hazard. Dislocation zones, especially faults with large uncemented fracture zones that are connected with waterbearing overburden can be a problem, and attention has to be paid to the hydrogeological and geomechanical properties of even consolidated formations (Table 1).
Considering all of these factors, the USCB can be subdivided differently, based on the potential water hazard sources:

- Region 1-In the northern and northeastern part of the USCB, most of the coal measures are hydrologically exposed to the overlying Triassic formations, which are the main hazard. These include sandy and loamy sediments of the Gaudy Sandstones as well as karstic carbonate sediments of the Upper Gaudy sandstones and a shell-bearing Limestone.

- Region 2-In the eastern part of the USCB, the weakly consolidated, easily deformed and eroded Carboniferous sandstones and conglomerates of the Łaziskie and Libiąskie Beds lie beneath permeable, often watersaturated, Quaternary formations.

- Region 3-In the south and southwest, the problems are caused by water-saturated sandy Quaternary and Miocene formations, as well as Miocene formations that contain karst-fissured gypsum, and the sandstones of the Dębowieckie Beds, which contains water and gas under high pressure, and is located just above the topmost coal seam. Most of region 3 would be classified as hydrologically isolated (subregion II).

Based on an assessment of geological structure and hydrogeological conditions, it was generally thought that mine shafts in the northern section would be less hazardous, while mines in the eastern section would have the greatest number of water inrushes. However, the two most recent inrush events both occurred in Region 3 (hydrogeologic subregion II), with dramatic results.

Since about 1970, the general dewatering of the carboniferous rock mass has reduced the incidence of water 


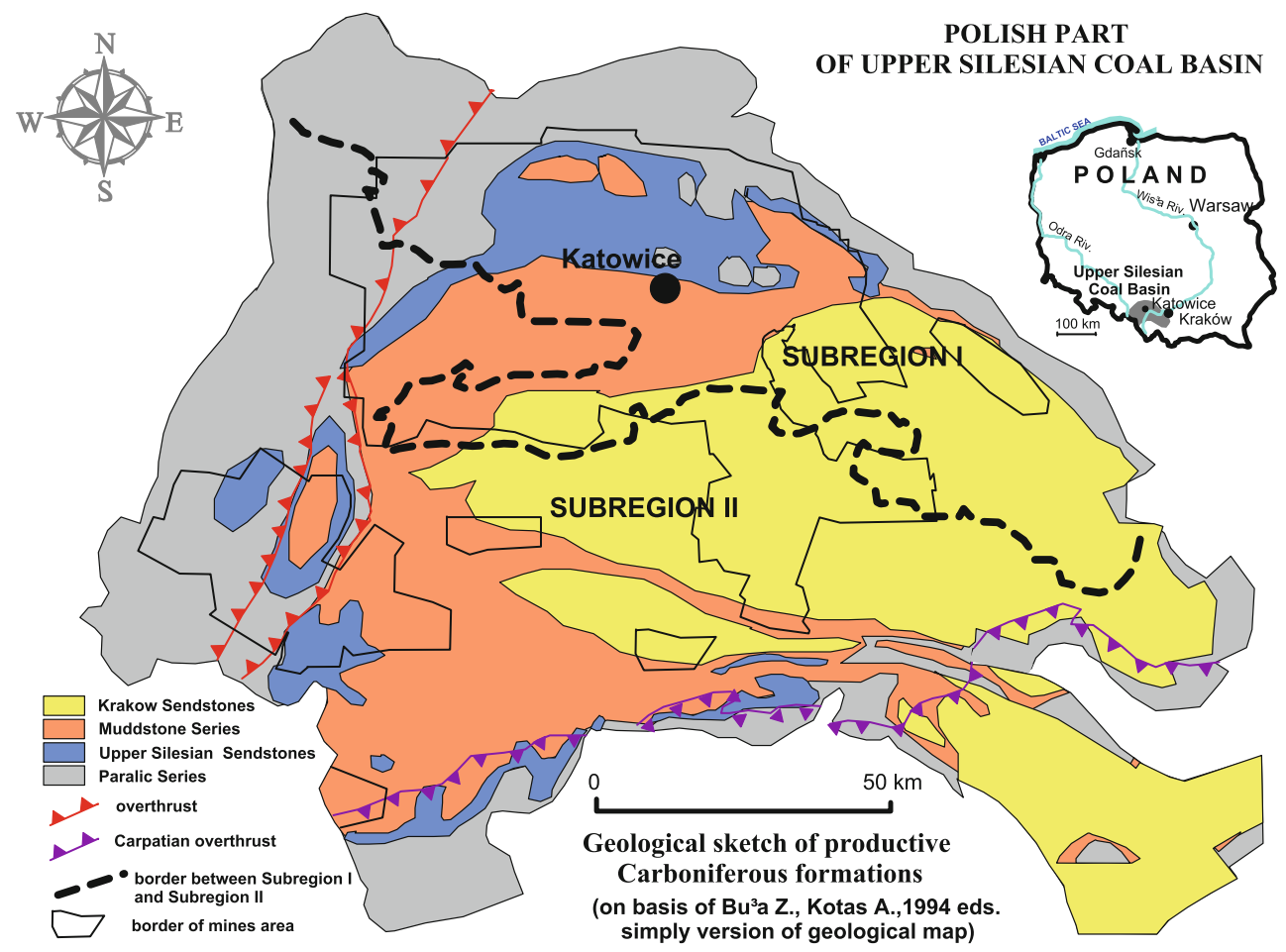

Fig. 2 Sketch of geological situation of productive Carboniferous formations in the Upper Silesian Coal Basin (based on a geological map published by Buła and Kotas (1994), showing the approximate

boundaries of the hydrogeologically exposed (subregion I) and isolated (subregion II) areas, according to Różkowski (2003)

Table 1 The characteristic range and median of uniaxial strength measurements, $\sigma_{\mathrm{cr}}$, in MPa (according to Bukowska 2009a, b) of deposit formations for the Upper Silesian Coal Basin (vide: Fig. 2)

\begin{tabular}{lrrrr}
\hline Rock & Paralic series & Upper Silesian Sandstones & Mudstone series & Krakow sandstones \\
\hline Sandstones & $25-117(80)$ & $41-114(70)$ & $30-102(62)$ & $2-72(14)$ \\
Mudstones & $32-109(70)$ & $18-136(62)$ & $21-101(56)$ & $21-35(27)$ \\
Siltstones & $20-93(47)$ & $14-78(43)$ & $12-77(39)$ & $12-33(21)$ \\
Coals & $5-47(24)$ & $2-50(22)$ & $4-44(15)$ & $14-46(30)$ \\
\hline
\end{tabular}

inrushes in USCB mines. Also contributing to that reduction has been the development of techniques to recognize and prevent water inrushes and the development of dewatering technology. Figure 3 illustrates the decrease in the number of water inrushes into active mine workings.

Since 1976, the inrush events have generally been relatively short in duration and not as dangerous as occurred earlier. Only three inrushes, which were loaded with loose rock material, occurred in shaft mine workings between 1977 and 1985. Associated subsidence events were also smaller.

Within Poland's USCB, mining is now taking place in strata with increased rock mass strength and less permeability, and the formations, in general, contain less water. In 1994, there was an intense inflow of quaternary waters from a cavity in a shaft of a mine in the southern part of the USCB, within the hydrogeologically covered area. The intensity of the inflow was about $2.0 \mathrm{~m}^{3} / \mathrm{min}$, and it stopped work in the mine shaft for about 1 day. All subsequent inrushes into shafts have also been in the hydrogeologically covered portion of the USCB, in the section of the shaft within the overburden strata, at a depth of about $100 \mathrm{~m}$.

As a result, investigations into water hazards have shifted to where the inrushes have lately occurred, within the hydrogeologically covered area, where the aquifers within the USCB overburden have caused problems, even though their water content is relatively low. Inflows into an average mine within the hydrogeologically isolated area in water hazard region 3 , with a mine area of about $30 \mathrm{~km}^{2} \pm$ several $\mathrm{km}^{2}$, range from 1 to $3 \mathrm{~m}^{3} / \mathrm{min}$, on average, and only sporadically exceed $10 \mathrm{~m}^{3} / \mathrm{min}$. Water production is very low and decreases with depth, while average mine depths has been increasing by about $8 \mathrm{~m}$ every year (Bukowska 2009a, b). The current average depth of mine 
Fig. 3 The chronological distribution of the 309 inrushes that have disrupted mining in the USCB in Poland since World War II; group I, in blue, represent inrushes that had surface reservoirs and streams, water-filled karstic caverns, and flooded mines as their source, and; group II, in grey, where the source of the inrushes were saturated strata, fractures zones, and boreholes

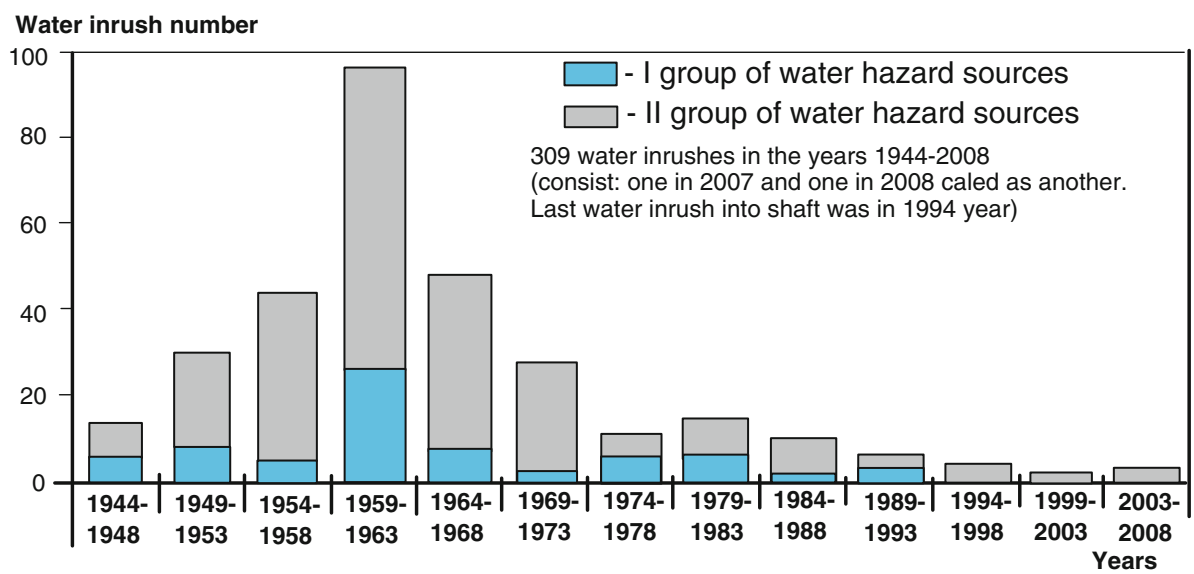

workings in the USCB is about $770 \mathrm{~m}$. A thick cover of Miocene loam effectively isolates the strata from surface water and the near-surface aquifers. One would think that there should be no serious water hazard sources, except for flooded goafs, to endanger the dewatering system of a mine. However, within this area are water-bearing overburden formations and some have turned out to be especially dangerous. Relatively thick layers of weakly consolidated water-saturated sands with relatively high water pressure (up to several $\mathrm{MPa}$ ), and water in karstic gypsum layers and sandy roof formations, i.e. the Dębowieckie Beds, which contain water and gas at pressures up to several tens of MPa (vide: Rogoż 2004).

Both of the inrushes that occurred during the last 3 years devastated the lining of ventilation shafts-one in the southwestern part of the USCB in 2007 and the other in the western part of the USCB in 2008. Perhaps more important though is that both incidents involved the incursion of water-saturated sand through rock that was thought to be impermeable. After both incidents, it was concluded that procedures had to be developed to assess the possibility of a similar event occurring in other mines in the USCB.

\section{The 2007 Incident in the SW Part of the USCB}

In December, 2007, a fast progressing subsidence basin was observed near ventilation shaft $\mathrm{V}$ above mine ' $\mathrm{A}$ ' (Fig. 4). The surface deformations corresponded with relatively shallow horizontal mine workings (locally referred to as a ventilation lunette) that connected the shaft with the main ventilation station. Meanwhile, underground, water
Fig. 4 Subsidence funnel next to ventilation shaft $\mathrm{V}$ of Mine A and uncovered cores of freezing bore-holes along ventilation lunette

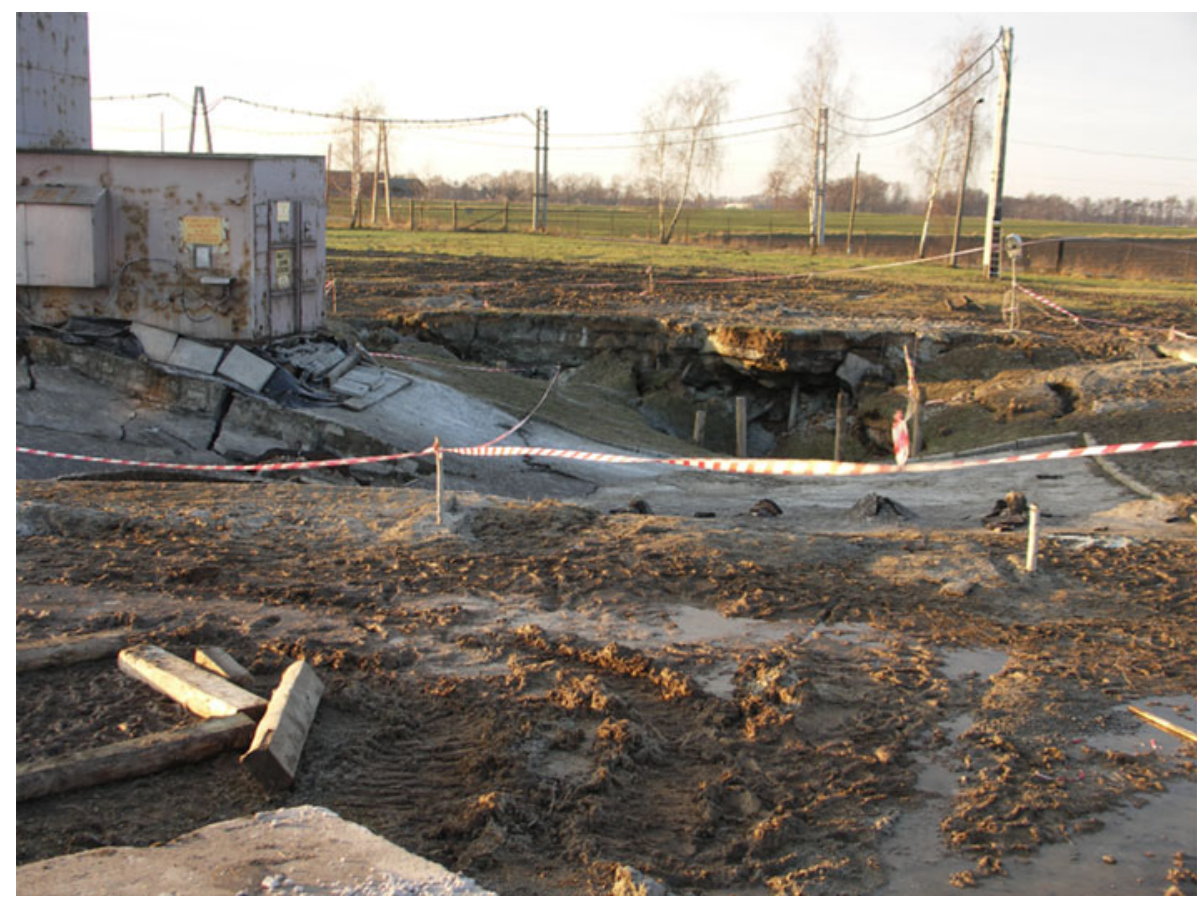


inflow rapidly increased and loose rock was observed falling to the bottom of the shaft, at a depth of more than $1,000 \mathrm{~m}$. In the ventilation lunette connected with the shaft at a depth of several tens of meters, water with rock material was noticed. The subsidence funnel that formed on the surface above the lunette eventually reached a diameter of several tens of meters and a depth of $4.5 \mathrm{~m}$. Its volume was estimated to be about $750 \mathrm{~m}^{3}$.

The event caused several potential hazards: the incursion of the water-saturated overburden material, subsidence, the danger of instability of the ventilation shaft, and as a consequence, a ventilation hazard (methane), which could have ended mining at the site. Observers stated that during the failure, that the connection of the ventilation lunette with the shaft pipe separated from the shaft entry and the lunette appeared to be "sinking" in the watersaturated fine-grained sand (Fig. 5).

The Quaternary strata in which the ventilation lunette was constructed consisted mainly of tills and silty clay. Unfortunately, the ventilation lunette connecting the shaft with the ventilator station (diffusers) was located at the bottom of a clay layer. During construction in the 1970s, a thixotropic silty-sand zone beneath the clay layer was penetrated. Construction in such conditions was possible using the rock mass freezing method (Yang and Wang 2005). The initial cause of the inrush in the shaft was probably associated with the use of this construction method atop the water-saturated sand. Technical difficulties in constructing the shaft and its underground connection with the ventilation station are evidenced by the many borehole cores from the freezing process appearing along its route (Fig. 4).

Using the freezing method during shaft construction inactivated the water around the construction area. After the shaft was constructed and the zone defrosted, the water- saturated formations were isolated by the shaft lining, though fine exudates and water leaks from behind the lining were observed. Water flowing from the area had a high load of suspended material but there were no alarming symptoms. Water inflow was not intense $\left(\mathrm{Q}<0.035 \mathrm{~m}^{3} /\right.$ min), and the location of the bottom of the shaft sump appeared to be stable, though it should be noted that it was always measured from the entry gallery side of the shaft at a level of $1,000 \mathrm{~m}$. Thus, it is not possible to completely exclude long-term mechanical suffusion of the sand formation and sedimentation of the rock material scoured from the other side of the shaft sump. In the 1980s, a rather small subsidence funnel appeared near the shaft and was filled with clay.

Although it is possible that suffusion and liquefaction of the water-bearing strata caused the failure, it appears more likely that a rock mass tremor caused by the mining, or vibrations associated with either the mining or the nearby station of ventilators, liquefied the thixotropic sands, essentially creating flowing quicksand. The lunette was located on the sand layer and so it started to crack laterally, and descend, under its own weight and the vertical pressure of the material lying above it, into the sand. The movement resulted in the exposure of the shaft pipe entry, through which water and water with suspended material, as well as fragments of the damaged lunette and shaft lining, fell.

The water hazard rapidly became a ventilation hazard for a significant part of the mine. The potential increase in methane concentrations and the hazards potentially associated with the subsidence funnel required rapid emergency operations, which proceeded with scientific support, including support from the Central Mining Institute. This resulted in closure of the entry to the shaft and water and rock mass immobilization (Tor et al. 2008). The outflow was dammed, reestablishing a water table within the

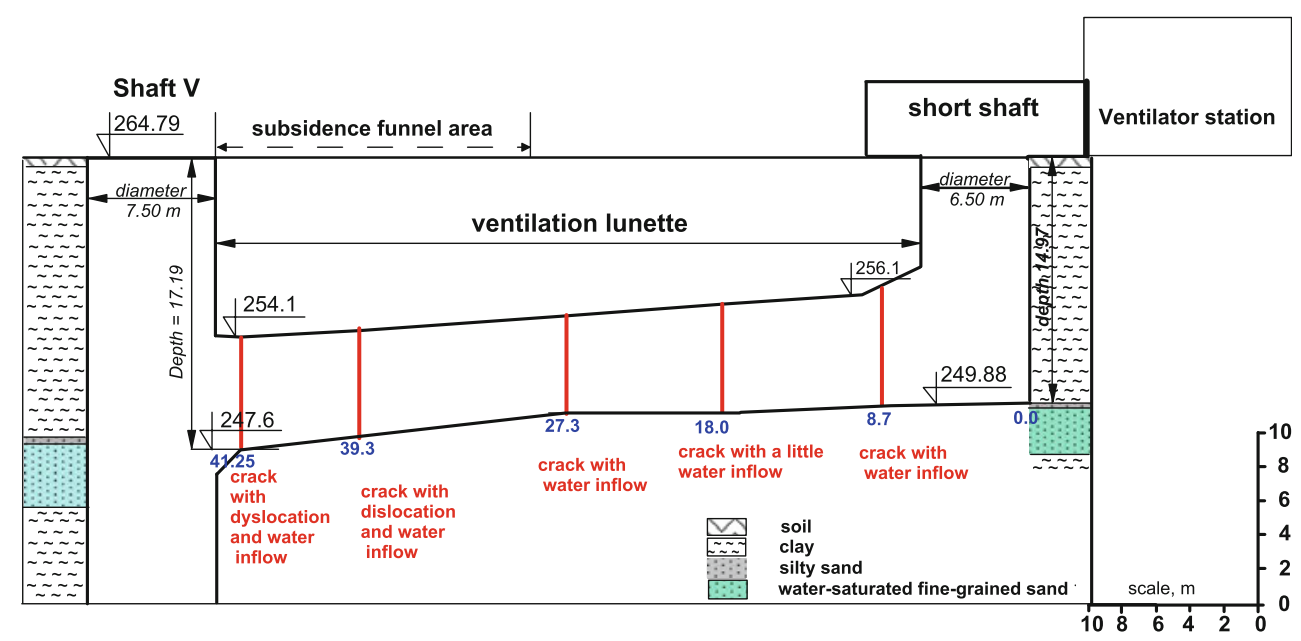

Fig. 5 The nature of shaft $\mathrm{V}$ and ventilation lunette construction at Mine 'A' and the initial symptoms of failure 
Fig. 6 The subsidence basin as it was being filled with clayOccurrence of water in the subsidence basin after closure of the entry to shaft V

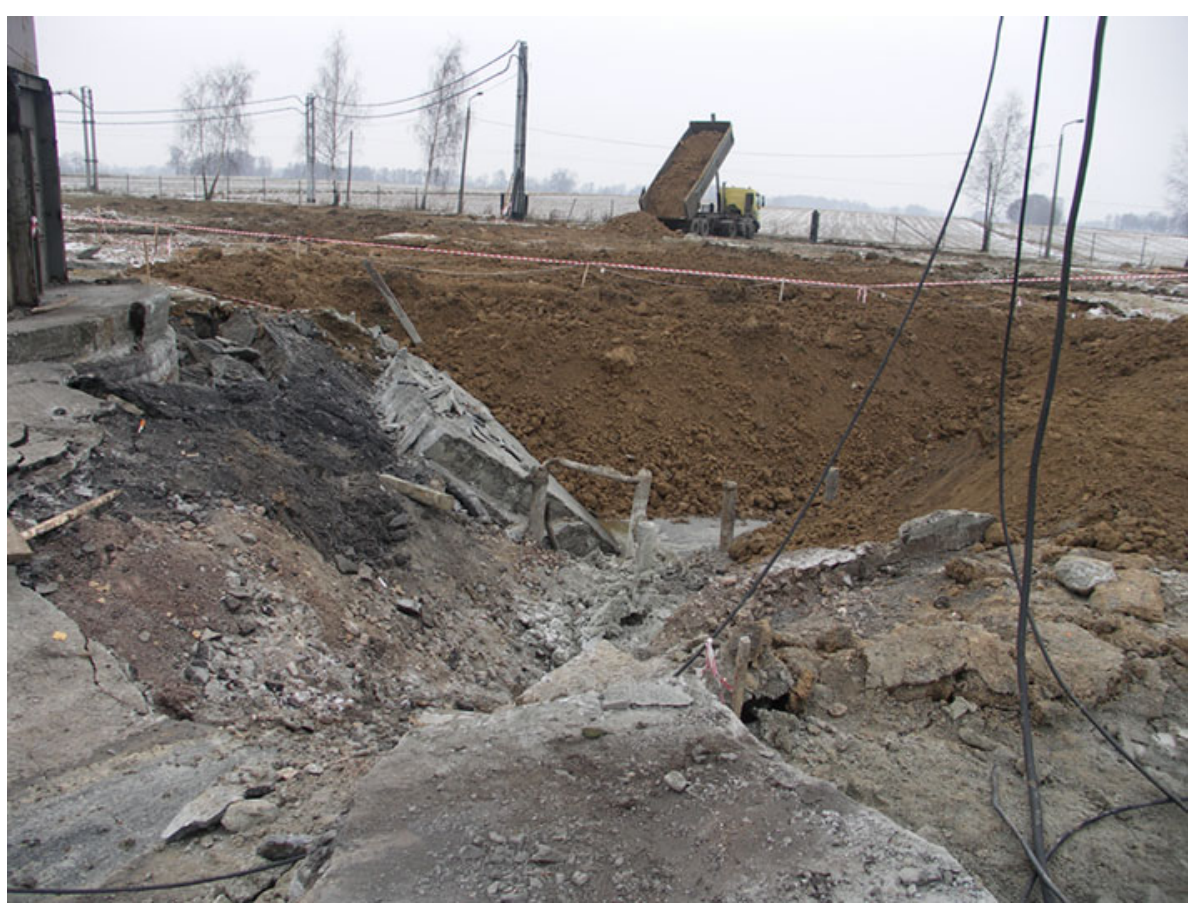

water-bearing stratum, revealed by the accumulation of water in the subsidence basin before it was filled (Fig. 6).

The water hazard was also fought from within the mine. At the bottom of shaft $\mathrm{V}$, at the $1,000 \mathrm{~m}$ level, a gypsum seal was established; from behind the seal, a series of drainage boreholes were drilled from within the mine workings to the shaft, allowing the water and suspended material to be drained. This reduced the rate at which the shaft was filling and helped reduce the water level in the reservoir of water that was accumulating above.

\section{The 2008 Incident in the Western Part of the USCB}

Mine 'B,' located in the western part of the Basin, had a near-catastrophe in September, 2008, as an undeveloped, unequipped exhaust shaft, also, ironically, referred to as shaft V, collapsed. Luckily, the event occurred on a Sunday and no one was injured or killed. After the event, a subsidence basin formed on the surface with a diameter of several tens of meters and a depth of about $15 \mathrm{~m}$ (Fig. 7).

The mine shaft had been constructed through up to $18.4 \mathrm{~m}$ of Quaternary overburden, consisting mainly of consolidated sedimentary rock, with two layers of watersaturated sands that were each up to $2 \mathrm{~m}$ thick. Paleogene formations lying below the Quaternary strata consisted of almost $20-35 \%$ of weakly consolidated water-saturated rocks (clayey sands and sandy clays) and a layer of watersaturated gypsum. Hydrogeological and geotechnical conditions were defined as good; the only unfavourable circumstance for construction of the shaft was the fact that it had been excavated in rock that had earlier been influenced by mining conducted nearby in a seam slightly deeper than the planned depth of the shaft. The shaft had been deepened without the necessity of rock mass freezing and without special construction techniques or dewatering. Total inflow to the shaft was defined as very small, about $0.020-0.035 \mathrm{~m}^{3} / \mathrm{min}$.

In hindsight, the probable reasons for the shaft collapse were the intense influence of nearby exploitation, and changes in water circulation, which in turn affected geotechnical conditions and ground properties around the shaft. The influences of exploitation were strengthened by the occurrence of disjunctive tectonics; faults in the deposit series formations intersected the mine shaft. The influences of exploitation were revealed by shaft pipe subsidence and numerous discontinuous deformations within the shaft and shaft pillar. Discontinuous deformations with different density, gaps, and dislocation were observed at the surface. In the vicinity of the shaft pillar, these resulted in hydrogeological changes. Around the head of the shaft, underground water circulation, infiltration, surface flow, and flow through the local sewer system, were all significantly changed as a result of deformation caused by the exploitation. Conditions around the shaft deteriorated and along the whole lithostratigraphic profile, there were changes in the strength and strain parameters of the Quaternary rock around the shaft, as well as an overall increase in humidity within the mine.

Initially, cracks and defects of the shaft lining resulted in exposure of the formation located around the shaft. The exposed rock fragments had a tendency to swell when 
Fig. 7 Results of the shaft failure in Coal Mine B; note remains of shaft tower in subsidence basin

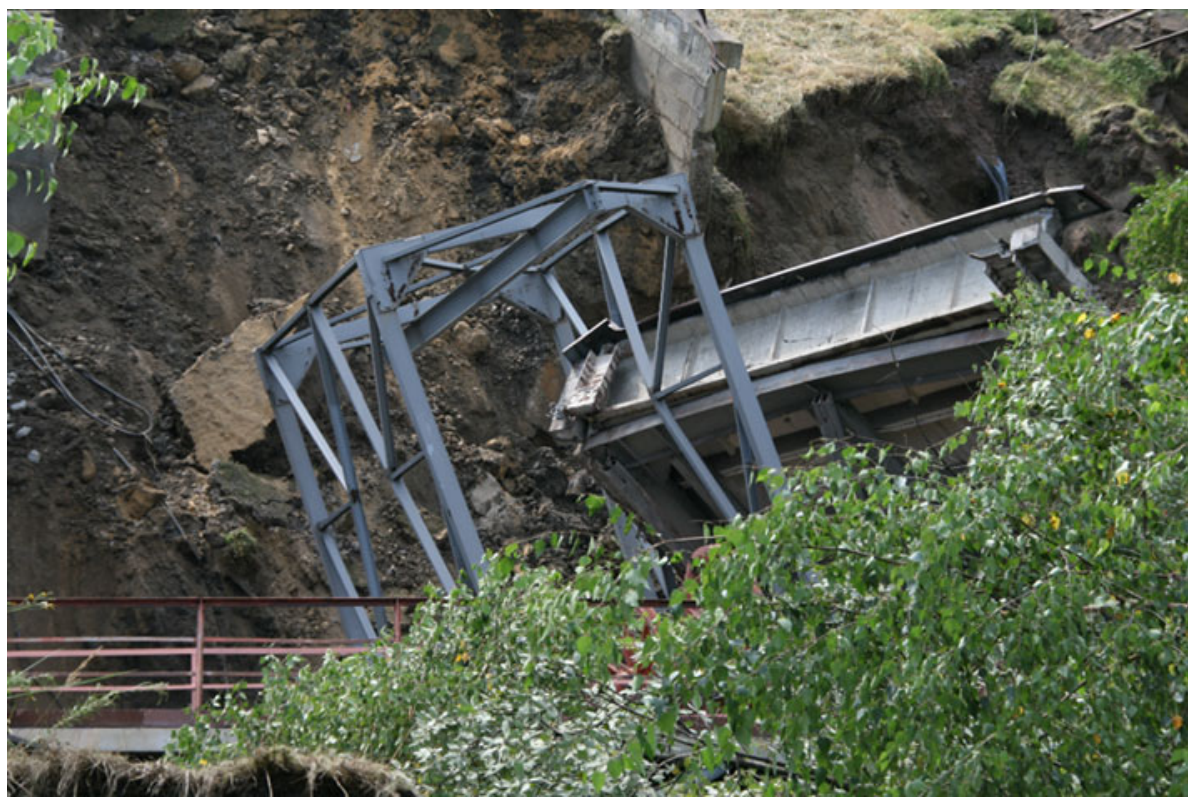

exposed to flowing water and/or water vapour condensation in the shaft, and fall into the shaft, destroying the shaft lining. Water-ground conditions that had been changed by the exploitation exposed small zones of unconsolidated water-bearing sands which, despite being small, intensified the movement of rock and water to the shaft. Increasing damage to the shaft lining, together with the increasing water load and the humid shaft atmosphere (a fog layer formed almost $200 \mathrm{~m}$ below the head of shaft) resulted in an unstable environment and the collapse of the shaft. This, in turn, led to the collapse of the surface structure, the formation of a deep subsidence basin, changes in the hydrology of the rock formations near the shaft, the accumulation of methane in the mine, and disturbance of ventilation in the neighbouring mine (Fig. 8).

All of the active mine workings in the area were threatened by the water-saturated material that filled the shaft conduit and the water that was accumulating in the subsidence basin, since the shaft provided a conduit for the water to reach all of the mine levels. Remedial action required the speedy construction of underground dams and seals in all mine workings connected to the shaft.

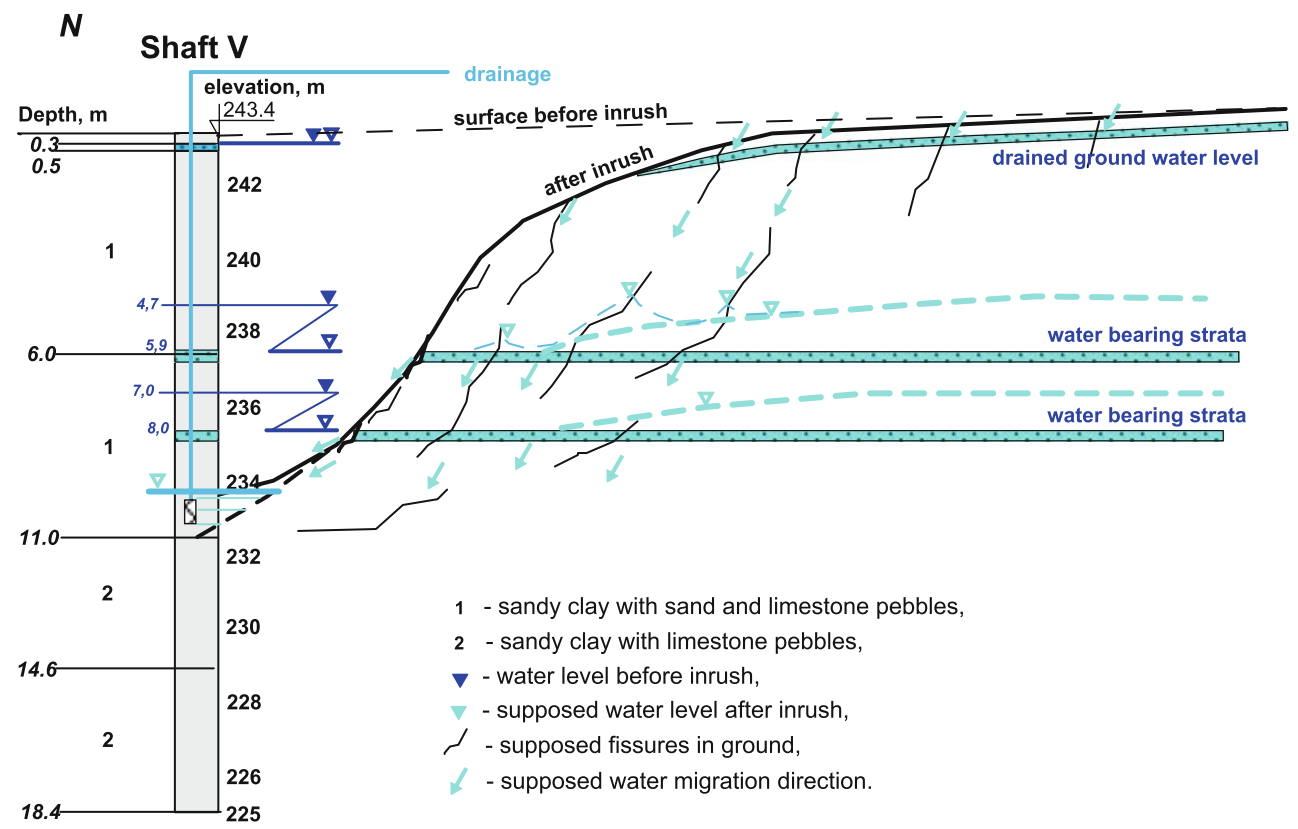

Fig. 8 Results of the inrush to the shaft and its influence on water conditions in the Quaternary formations around the shaft 


\section{A Proposed Method to Assess Water Hazards in Shafts}

Both of these events revealed imperfections in monitoring, classification, and assessment of potential water hazards in Polish mines. Active mine shafts are not classified as potential water hazards, although they do provide potential routes of water migration, connecting many mine levels. The only barrier between the mine shaft and the water-bearing strata is the relatively thin shaft lining, and once that fails, the shaft can flood or fill with fluidized rock material.

The recent events within the hydrogeologically covered area in the USCB show that even in conditions thought to be safe, serious hazards may exist. Both events show how important it is to recognize hydrogeological and engineering conditions and to monitor them especially carefully when mining activities in the area intensify. To determine how safe a mine shaft is, it is necessary to trace the history of shaft construction, understand the original water-ground conditions, evaluate the state and behavior of rock mass, assess whether the hydrological properties of overburden and interburden strata are changing (Bukowska 2005, 2006; Bukowska 2009a, b; Bukowski and Bukowska 2008), and whether changes are occurring at the surface or underground adjacent to the shaft.

The author has summarized these factors in a potential hazard chart (Table 2) for use in the USCB. It is based on an analytical and empirical analysis of seven main factors (WODSHIP) that can be used to assess the likelihood of a water hazard occurrence. Generally, the weight of a given factor in Table 2 is based on how widely it has been recognized as significant in mining, hydrogeological, and geomechanical studies. The most important of these, designated as $\mathrm{R}=3$ on Table 2 , are the volume of water inflow (I), the amount of total suspend solids (W), and the conditions of the shaft lining (S). Among these factors, only the last one is subjective as it requires an assessment of lining damage.

Factors such as the condition of the shafts pillars $(\mathrm{P})$ and the proportion of saturated overburden formations (O) should be considered in the assessment of water hazards in shafts; however, they are less important $(\mathrm{R}=2)$ than factors designated as $\mathrm{R}=3$.

The pillar within which the exploitation is conducted is assumed to be adversely influenced by exploitation. The condition of a shaft pillar is based on the scope of exploitation in its vicinity. The influence of mining on shaft pillars and shafts may be determined in the same manner as is used in safety pillar analysis, as, for example, for large water reservoirs (Bukowski 2009, 2010). There are methods to assess the influence of rock mass tremors on pillar and shaft behavior (Mutke 2008) as well as methods to assess the extent of surface subsidence and vertical and horizontal deformations (Knothe 2005; Kowalski 1985).
The factor describing a deposit (D) is of minor importance $(R=1)$. It is related to the degree of rock mass drainage and simultaneously points at possibilities of changes of geomechanical properties of the strata in the vicinity of a shaft. The history of a shaft $(\mathrm{H})$ is also considered of minor importance $(\mathrm{R}=1)$, since clues provided by the history of a shaft are usually only recognized in hindsight.

With respect to safety, attention should be paid to the correlation of individual factors, especially $\mathrm{R}=3$ and $\mathrm{R}=2$ factors. Generally, the $\mathrm{R}=1$ factors (the history of the shaft and water-bearing strata in the deposit (interburden) are significant only when $\mathrm{R}=2$ and $\mathrm{R}=3$ factors are elevated. In contrast, even one $\mathrm{R}=3$ factor or, two $\mathrm{R}=2$ factors with a high or very high hazard ranking indicate potential areas of concern with the shaft, and the need for a detailed analysis to better assess the potential of a water hazard.

This classification may be viewed as the potential basis of an expert classification system, and is based on methodology used by others (e.g. the DRASTIC system by Aller et al. 1987), where the weighting would be assigned based on the assigned importance number of the $\mathrm{R}$ factors, as indicated in Table 2, ranging from $\mathrm{R}=1$ to $\mathrm{R}=3$. However, development of such an expert system requires more analysis on whether or not to include other natural, mining, and technical factors. It may also be possible to adapt this approach to different geological and mining conditions.

\section{Summary}

Since 1976, there have been six inrushes of water into shaft mine workings in the Upper Silesian Coal Basin, with two of the more serious events occurring during the last 3 years, despite the fact that since the 1990s, almost half of the mines in the USCB have been abandoned. Since such an event in a mine shaft can threaten the entire mine workings, it is important that these potential hazards be defined as early as possible, and that monitoring of key factors be instituted at potentially hazardous sites. Ironically, old ventilation mine shafts (often no longer containing equipment), once constructed, are sometimes monitored less rigorously than other mine components. After an analysis of the documented inrush events, certain factors were identified that could be useful in assessing shaft safety, relative to inrush events. These are the amount of water flowing into the shaft, the amount of suspended material contained in the water flowing into the shaft, the proportion of water-bearing formations in the vertical profile, the condition of the shaft lining and safety pillar, and the history of the shaft. Each of these risk factors was 


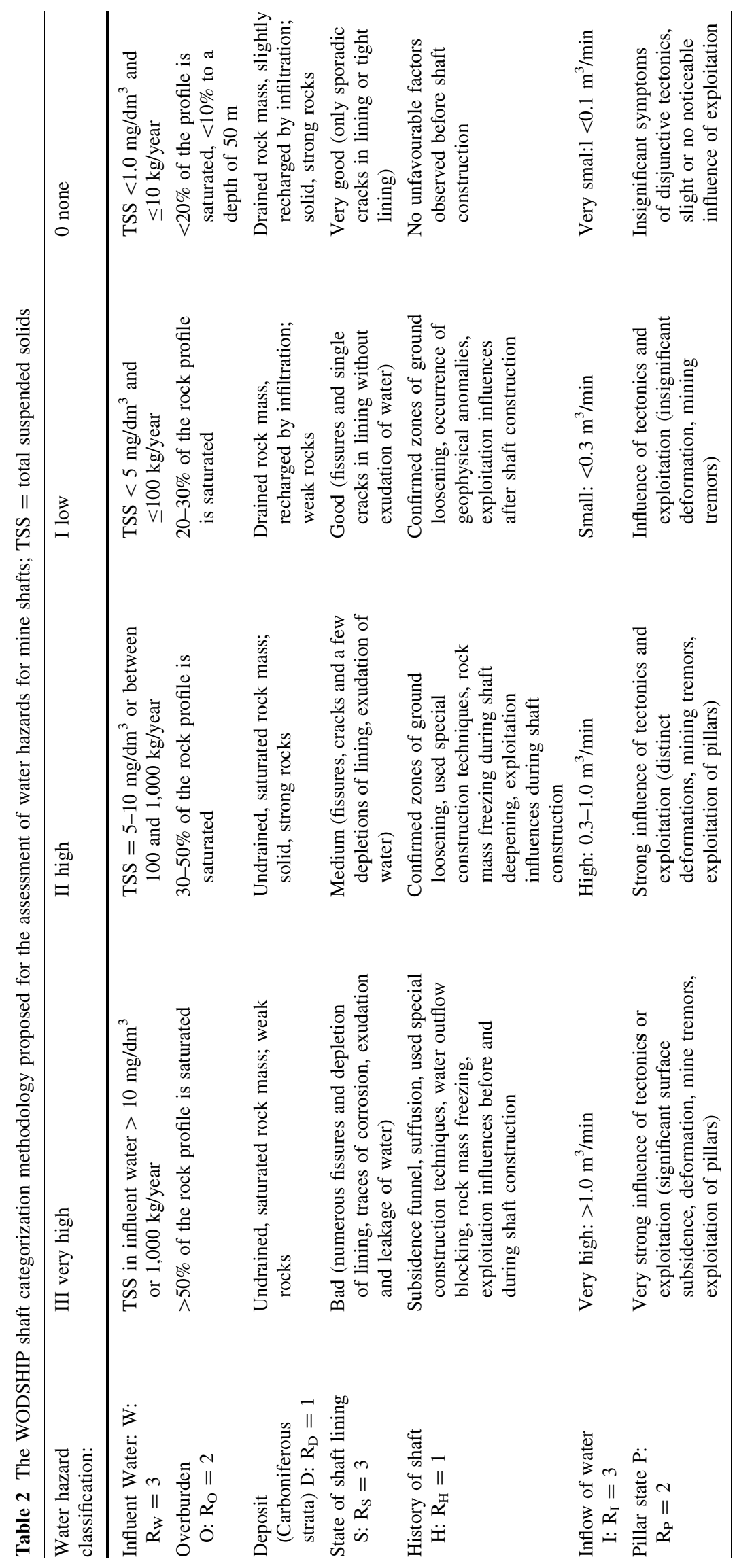


assigned a weight, based on their perceived relative significance, and then a method of evaluating each of these factors was developed, using a categorization from category 0 to III. In the author's opinion, the proposed assessment approach could be the basis for a more detailed, expert system for timely assessment of water hazard risk analysis. It may also be possible to adapt it to different geological and mining conditions.

Acknowledgments This work was financed by Poland's Ministry of Science and Higher Education as a part of scientific project N524 467036.

Open Access This article is distributed under the terms of the Creative Commons Attribution Noncommercial License which permits any noncommercial use, distribution, and reproduction in any medium, provided the original author(s) and source are credited.

\section{References}

Aller L, Bennet T, Lehr JH, Petty RJ (1987) DRASTIC: a standardized system for evaluating groundwater pollution potential using hydrogeological settings. US EPA Report 600/2-85/018, Washington

Bukowska M (2005) Mechanical properties of Carboniferous rocks in the Upper Silesian Coal Basin under uniaxial and triaxial compression tests. J Min Sci 41(2):129-133

Bukowska M (2006) The probability of rockburst occurrence in the Upper Silesian Coal Basin area dependent on natural mining conditions. J Min Sci 42(6):570-577

Bukowska M (2009a) The exploitation depth and bump hazard in the mines of the Upper Silesian Coal Basin. In: Sobczyk EJ, Kicki J, Saługa P (eds) Proc, deep mining challenges, international mining forum. CRC Press, Taylor and Francis Group/Balkema, London, pp 23-32

Bukowska M (ed) (2009b) A complex method of the assessment of a rock mass susceptibility to bums in the Upper Silesian Coal Basin. In Polish, abstract in English, Wydawnictwo GIG, Katowice, Poland, p 194

Bukowski P (2009) Determining of water hazard zones for mining exploitation planned in the vicinity of reservoirs in abandoned mines. Wydawnictwo Sigmie PAN Kraków, Poland, Gospodarka Surowcami Mineralnymi (Miner Resour Manage) 25(3):203-215

Bukowski P (2010) Determining of safety pillars in the vicinity of water reservoirs in mine workings within abandoned mines in the Upper Silesian Coal Basin (USCB). J Min Sci 46(3):57-69
Bukowski P, Bukowska M (2008) Changes in geomechanical properties of Carboniferous rocks under the influence of water and their possible consequences in the areas of abandoned mines of the Upper Silesian Coal Basin (Poland). In: Rapantova H (ed) Proceedings, 10th congress of the international mine water association (cd), Karlovy Vary, Czech Republic, p 5

Bukowski P, Bromek T, Augustyniak I (2006) Using the DRASTIC system to assess the vulnerability of ground water to pollution in mined areas of the Upper Silesian Coal Basin. Mine Water Environ 25(1):15-22

Buła Z, Kotas A (eds) (1994) Geological Atlas of the Upper Silesien Coal Basin, part 3, geological-structural maps. 1: 100 000, in Polish. Wydawnictwo PIG, Warszawa

Knothe S (2005) Asymmetric function of distribution of mining exploitation influences in the medium with changing properties. Arch Min Sci 50(4):401-415

Konstantynowicz E (1971) The methodology of investigations, prophylaxis and the protection of mining excavations in mines of carbon before the inrush of water or the watered sands. In Polish, Przegląd Górniczy nr 3, Katowice, Poland, pp 135-147

Kowalski A (1985) Changeability of the parameter of main influence reach in rock mass. In Polish. Ochrona Terenów Górniczych 72(2): $17-23$

Marchacz W, Szczepańska-Bereszko K, Bromek T, Piłat T, Posyłek E, Rogoż M (1965) The geological factors and the source of water hazard in hard coal mines. In Polish, Mat. Konf. Zwalczanie zagrożeń wodnych kopalniach węgla kamiennego, SITG-NOT

Mutke G (2008) Stability of the underground mine workings in the near field zone of seismic events. Proceeding, new challenges and visions for mining. 21st world mining congress: underground mine environment. The Fundation for the AGH, Kraków, Poland, pp 89-97

Rogoż M (2004) Mining hydrogeology with foundations of general hydrogeology. In Polish. Wydawnictwo Głównego Instytutu Górnictwa w Katowicach, Katowice, p 683

Różkowski A (2003) Geological and hydrogeological conditions in the USCB. In: Wilk Z (ed) In Polish, Proc, Hydrogeologia polskich złóż kopalin i problemy wodne górnictwa, cz 1 . Wydawn. Naukowo-Dydaktyczne AGH, Kraków, pp 42-145

Tor A, Jakubów A, Tobiczyk S (2008) Hazards result in damage of ventilation lunetce of the shaft $\mathrm{V}$ in the Jastrzębska Spółka Węglowa SA, KWK "Pniówek" in Pawłowice. In Polish, ISSN 1730-7848, Wyd Drekop, Wrocław, Poland 71(2): 47-56

Wilk Z (2003) Hydrogeology of Polish mineral deposits and water problems of mining. In Polish, Uczelniane Wydawnictwa Naukowo-Dydaktyczne AGH, part 1, Kraków, Poland, p 611

Yang C, Wang Z (2005) Surface Pre-grounting and freezing for shaft sinking in aquifer formations. Mine Water Environ 24(4):209-212 